\title{
Determination of fertility traits of sheep and growth characteristics of Chios crossbred male lambs reared under local breeder conditions
}

\section{Research Article}

Volume: 4, Issue: 3 December 2020

Pages: 102-108

\section{Article History}

Received: 01.10.2020

Accepted: 17.10.2020

Available online:

28.10.2020

\author{
ilhan íRiM ${ }^{1}$, Aykut Asım AKBAŞ ${ }^{2 *}$, Mustafa SAATCl ${ }^{3}$
}

1. Degree of Veterinary Medicine, Döşemealt District Directorate of Agriculture and Forestry, Antalya, Turkey. 2. Department of Animal Science, Faculty of Veterinary Medicine, Burdur Mehmet Akif Ersoy University, Burdur, Turkey. 3. Department of Animal Science, Fethiye Faculty of Agriculture, Muğla Sıtkı Koçman University, Muğla, Turkey.

I. Irim ORCID: 0000-0003-3422-195. A.A. Akbaş ORCID: 0000-0003-2235-9439. M. Saatcı ORCID: 0000-0003-3697-8804.

\begin{abstract}
This study was conducted to determine the fertility of Chios $x$ Kivircık and Chios $x$ Cine Caparı crossbreed sheep ( 94 ewes) and the growth characteristics and liveability values of crossbred lambs (62 male kids) under local breeder conditions. The birth and lamb rate and litter size values of Chios x Kıvırcık ewes and Chios x Cine Caparı ewes were detected as $93 \%, 1.21$ and $1.29 ; 93 \%, 1.12$ and 1.20 . respectively. The liveability traits of crossbred lamb for each genotype on the 120 th day of age were $81.06 \%$ and $84.00 \%$, respectively. The average live weights on birth and 120th day of age were detected as $3.97 \mathrm{~kg}$ and $26.89 \mathrm{~kg} ; 3.86 \mathrm{~kg}$ and $25.86 \mathrm{~kg}$, respectively. For the same periods, the average of body measurements such as height at withers, rump height, body length and chest girth were detected as $38.08 \mathrm{~cm}, 38.27 \mathrm{~cm}, 35.79 \mathrm{~cm}$ and $37.76 \mathrm{~cm} ; 59.67 \mathrm{~cm}$, $59.61 \mathrm{~cm}, 57.18 \mathrm{~cm}$ and $74.71 \mathrm{~cm}$ respectively for Chios $\times$ Kivircık lambs and also determined as $37.18 \mathrm{~cm}, 37.49 \mathrm{~cm}, 35.36 \mathrm{~cm}$ and $36.59 \mathrm{~cm} ; 59.44 \mathrm{~cm}, 59.30 \mathrm{~cm}, 56.68$ $\mathrm{cm}$ and $74.43 \mathrm{~cm}$, respectively for Chios $x$ Cine Caparı lambs. While flocks had an statistically significant effect in generally on all growth periods, except birth; differences between genotypes were statistically significant for the last two measurement periods. It was thought that the animals having higher production levels and also adaptability could be reared in the region with suitable management, breeding and crossbreding systems.
\end{abstract}

Keywords: Chios, crossbreeding, fertility, growth

* This study was prepared from first author's master thesis.

DOI: https://doi.org/10.30704/http-www-jivs-net.803490

To cite this article: Irim, I., Akbas, A. A., Saatci, M. (2020). Determination of fertility traits of sheep and growth characteristics of Chios crossbred male lambs reared under local breeder conditions. Journal of Istanbul Veterinary Sciences, 4(3), 102-108. Abbreviated Title: J Ist Vet Sci

\section{Introduction}

Livestock activity includes positive contributions in terms of utilizing labor force idle and animal feed, allowing regular cash flow and decreasing risk in the enterprise and migration from the rural are (Öztürk and Karkacier, 2008). Sheep breeding, which is one of the mentioned livestock activities, has been performed

*Corresponding Author: Aykut Asım Akbaş

E-mail: icould_akbas@hotmail.com in different locations from time immemorial. The fact that there is no need for expensive animal shelter and equipment as in the other livestock activities in sheep breeding, most of the ration need is met by roughage, and this roughage is mostly met from pasture makes sheep breeding a livestock branch with low input

Journal home page: www.jivs.net http://dergipark.gov.tr/http-www-jivs-net 
(Ergün et al., 2006). Through sheep breeding, which has an important place among animal production activities in the world, the pastures and grazing lands, which are not used for other purposes in various countries, are used as far as possible (Günaydın, 2009). The geographical location, pasture structure, and climate conditions of Turkey provide the appropriate conditions for sheep breeding. When considering this situation, the importance of sheep breeding increases further; the adaptation skill of sheep in the areas where agricultural production is unproductive shows that the developing countries such as Turkey may turn this disadvantage into an opportunity (Görür et al., 2012). In Anatolian culture, sheep has a material and moral value and sheep breeding in Turkey is performed in agricultural enterprise or in the form of village herds, plateau or migratory herds (Yılmaz et al., 2014) The current population of sheep which exceeds 37 million (Turkish Statistical Institute, 2020) is mostly composed of the populations including native breeds with low yield and feeding is mainly performed based on grazing (Ertuğrul et al., 2010). When considering that majority of the sheep breeds in Turkey are composed of the breeds with low yield, many improvement studies are performed in terms of increasing the mentioned yield. Chios breed, which has a thin, fat-free and long tail and is included in prolific breeds (Hatziminaoglou et al., 1996), is one of the important breeds used for this purpose.

It is remarkable that the studies on native sheep breeds in Turkey are generally performed in public enterprises. However, the studies on determining the morphological and physiological characteristics and the yield of sheep in breeder conditions have importance in terms of providing the performance of more effective livestock development policies (Karaca et al., 1996). In this respect, it is understood that the yield levels of animals should be revealed through the studies to be conducted under local breeding conditions.

The aim of the current study was to investigate the fertility of Chios x Kıvırcık (CK) and Chios $x$ Cine Caparı (CC) crossbreed sheep and the growth characteristics and survival rates of crossbred lambs.

\section{Materials and methods}

Animals and data collection: The present study was carried out in Chios x Kivircik (F1) and Chios x Cine Caparı (F1) crossbreed flocks reared under local breeder condition in Bekilli district of Denizli province. The five flock which consisted for aim of a project conducted with a local foundation under breeder conditions were detected. 2 years old dams were provide the all farmers fitting the purpose of local foundation's project.

While some fertility traits such as conception rate, birth rate, lamb rate and litter size were performed described by Akcapınar (2000) of 94 ewes, the birth weights, live weights and some morphological body measurements such as height at withers, rump height, body length and chest girth of 62 single male lambs described by Elmaz et al. (2011) indicative for growth characteristics until 120th day of age were defined.

In general, the animals in all the flocks followed were kept at pasture between 06:00 and 18:00 at the times when pasture was suitable. They were additionally fed by barley/wheat feed grinder when they returned back from pasture. After the lambs lived with their mothers for about one month after delivery, they were taken to a place without their mothers and they were allowed to suck milk from their mothers twice a day as one in the morning and one in the evening. The lambs continued to suck milk until they were at the age of 3 months and after this period, they started to be taken to pasture together with the sheep. In addition, after the lambs were 1 month old, they were fed with lamb grower feed.

As the measurements of the lambs used in the study were performed in the flocks, no additional care and feeding condition was provided for the animals. Also, no hybridization system was applied in the flocks followed similarly and the hybrid herds distributed to the breeders within the scope of the project mentioned above and, therefore, the flocks at F1 level raised locally under the current conditions were explored on site and the sizes of these crossbred lambs were measured.

Statistical analyses: All statistical analyses were carried out using Minitab 16.1 statistical package (2010). A descriptive statistical analysis was applied on the data related to reproduction characters. ChiSquare test was used for statistical evaluation of the data in order to compare survival rates of lambs for different examination periods.

A statistical model with the fixed effects (genotype and flocks) was used for determining the least square (LS) means of the weight and body measurement traits. The effects of the factors with their interactions on growth performance were analyzed by using generalized linear model (GLM) procedure with birth weight as a linear covariate. When the dual interactions between the groups were examined, the interaction analyses were not performed since no statistical significance was found. Additionally, Tukey's analysis was employed in controlling significance of differences between subgroups $(P<0.05)$. 


\section{Results}

Some fertility characteristics of five different Chios $x$ KIvırcık (CK) and Chios $x$ Cine Caparı (CC) flocks were presented in Table 1 . While the conception rate, birth rate, lamb rate, litter size, single birth rate and twinning rates in Chios x Kıvırcık crossbred sheep were found to be $98 \%, 93 \%, 1.21,1.29,71 \%$ and $29 \%$ respectively, the same values were detected as $97 \%$, $93 \%, 1.12,1.20,80 \%$ and $20 \%$ for Chios $x$ Cine Caparı crossbred sheep respectively.
Tables (3-7) show the means of least squares according to genotype and flocks of the birth weight and weaning (120th day) weight and also some body measurement traits, examined as the growth traits of CK and CC lambs. In the study, it was determined that the LS-means of birth weights of CK and CC male lambs were $3.97 \mathrm{~kg}$ and $3.86 \mathrm{~kg}$, respectively. While, some body measurement values such as height at withers, rump height, body length, and chest girth values on

Table 1. Some fertility traits of Chios x Kıvırcık and Chios x Cine Caparı crossbreed sheep

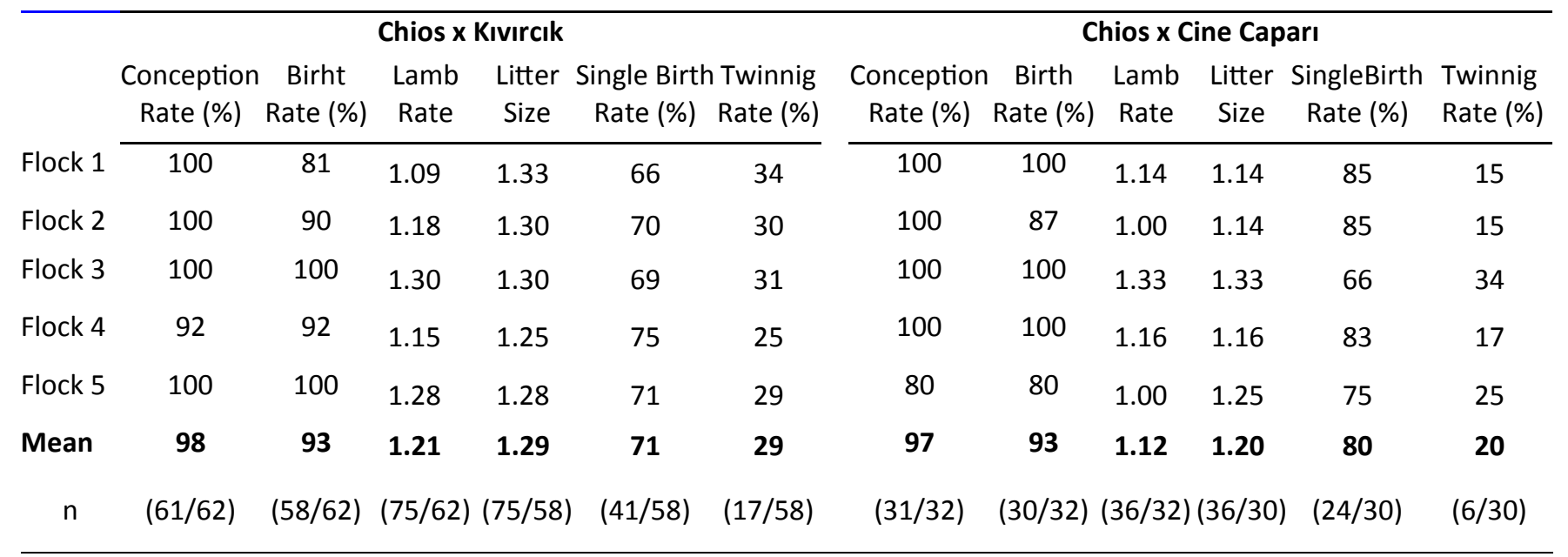

Table 2 shows the survival rates of the male lambs in the examined flocks until the 120th day. In the study, in general, it was observed that the 0-30th, 060th, 0-90th and 0-120th day survival rate values of CK crossbred lambs were 93.28\%, 83.60\%, 81.06\%, and $81.06 \%$; whereas, the survival values CC lambs in the same periods were $88.00 \%$ and $84.00 \%$, for the last three periods. the birth were $38.08 \mathrm{~cm}, 38.27 \mathrm{~cm}, 35.79 \mathrm{~cm}$, and $37.76 \mathrm{~cm}$ for the $\mathrm{CK}$ lambs, these values were respectively $37.18 \mathrm{~cm}, 37.49 \mathrm{~cm}, 35.36 \mathrm{~cm}$, and 36.59 $\mathrm{cm}$ for the CC lambs. The differences between genotype and flocks were statistically significant in terms of only chest girth value at birth $(P<0.05)$.

Live weights at the 30th, 60th, 90th, and 120th days of age were $8.70 \mathrm{~kg}, 16.75 \mathrm{~kg}, 22.02 \mathrm{~kg}$ and 26.89

Table 2. Survival rates of Chios x Kıvırcık and Chios $x$ Cine Caparı crossbreed male lambs (\%)

\begin{tabular}{|c|c|c|c|c|c|c|c|c|c|c|c|c|c|c|c|c|c|c|c|c|}
\hline & \multicolumn{10}{|c|}{ Chios x Kıvırcık } & \multicolumn{10}{|c|}{ Chios x Cine Caparı } \\
\hline & \multicolumn{2}{|c|}{ Birth } & \multicolumn{2}{|c|}{ 30th day } & \multicolumn{2}{|c|}{ 60th day } & \multicolumn{2}{|c|}{ 90th day } & \multicolumn{2}{|c|}{ 120th day } & \multicolumn{2}{|c|}{ Birth } & \multicolumn{2}{|c|}{ 30th day } & \multicolumn{2}{|c|}{ 60th day } & \multicolumn{2}{|c|}{ 90th day } & \multicolumn{2}{|c|}{ 120th day } \\
\hline & $\mathrm{n}$ & $\%$ & $n$ & $\%$ & $\mathrm{n}$ & $\%$ & $\mathrm{n}$ & $\%$ & $\mathrm{n}$ & $\%$ & $n$ & $\%$ & $\mathrm{n}$ & $\%$ & $\mathrm{n}$ & $\%$ & $n$ & $\%$ & $\mathrm{n}$ & $\%$ \\
\hline Flock 1 & 5 & 100 & 5 & $100^{a}$ & 4 & $80.00^{c}$ & 4 & $80.00^{b}$ & 4 & $80.00^{b}$ & 5 & 100 & 4 & $80.00^{b}$ & 4 & $80.00^{b}$ & 4 & $80.00^{b}$ & 4 & $80.00^{b}$ \\
\hline Flock 2 & 8 & 100 & 7 & $87.50^{b}$ & 7 & $87.50^{b}$ & 7 & $87.50^{\mathrm{a}}$ & 7 & $87.50^{\mathrm{a}}$ & 5 & 100 & 5 & $100^{a}$ & 5 & $100^{a}$ & 5 & $100^{a}$ & 5 & $100^{a}$ \\
\hline Flock 3 & 5 & 100 & 5 & $100^{\mathrm{a}}$ & 4 & $80.00^{c}$ & 4 & $80.00^{b}$ & 4 & $80.00^{b}$ & 5 & 100 & 4 & $80.00^{b}$ & 4 & $80.00^{b}$ & 4 & $80.00^{b}$ & 4 & $80.00^{b}$ \\
\hline Flock 4 & 9 & 100 & 8 & $88.89^{b}$ & 7 & $77.80^{c d}$ & 7 & $77.80^{b}$ & 7 & $77.80^{\mathrm{b}}$ & 5 & 100 & 4 & $80.00^{b}$ & 4 & $80.00^{b}$ & 4 & $80.00^{b}$ & 4 & $80.00^{b}$ \\
\hline Flock 5 & 10 & 100 & 9 & $90.00^{b}$ & 9 & $90.00^{a}$ & 8 & $80.00^{b}$ & 8 & $80.00^{b}$ & 5 & 100 & 5 & $100^{\mathrm{a}}$ & 4 & $80.00^{b}$ & 4 & $80.00^{b}$ & 4 & $80.00^{b}$ \\
\hline Mean & 37 & 100 & 34 & 93.28 & 31 & 83.60 & 30 & 81.06 & 30 & 81.06 & 25 & 100 & 22 & 88.00 & 21 & 84.00 & 21 & 84.00 & 21 & 84.00 \\
\hline$P$ & & NS & & $* *$ & & $* *$ & & $* *$ & & $*$ & & NS & & $* *$ & & $* *$ & & $* *$ & & $* *$ \\
\hline
\end{tabular}

$\mathrm{a}, \mathrm{b}, \mathrm{c}, \mathrm{d}$ : Values in the same column with different superscripts are statistically different $(\mathrm{P}<0.05)$. NS: nonsignificant $(\mathrm{P}>$ 0.05). *: $\mathrm{P}<0.05, * *: \mathrm{P}<0.01$. 
Table 3. Least square means for the effects of genotype and flock on growth traits of Chios x KIvırcık and Chios $x$ Cine Caparı crossbreed male lambs at birth ( \pm )

\begin{tabular}{|c|c|c|c|c|c|c|}
\hline Factor & $\mathrm{n}$ & $\begin{array}{c}\text { Birth Weight } \\
(\mathrm{kg})\end{array}$ & $\begin{array}{l}\text { Height at Withers } \\
\qquad(\mathrm{cm})\end{array}$ & $\begin{array}{l}\text { Rump Height } \\
\text { (cm) }\end{array}$ & Body Length $(\mathrm{cm})$ & $\begin{array}{c}\text { Chest } \\
\text { Girth }(\mathrm{cm})\end{array}$ \\
\hline \multicolumn{7}{|l|}{ Genotype } \\
\hline Chios x Kıvırcık & 37 & $3.97 \pm 0.04$ & $38.08 \pm 0.24$ & $38.27 \pm 0.22$ & $35.79 \pm 0.13$ & $37.76^{a} \pm 0.22$ \\
\hline $\begin{array}{c}\text { Chios x Cine Caparı } \\
\text { P values }\end{array}$ & 25 & $\begin{array}{c}3.86 \pm 0.06 \\
0.213^{\text {ns }}\end{array}$ & $\begin{array}{c}37.18 \pm 0.33 \\
0.072^{\text {ns }}\end{array}$ & $\begin{array}{c}37.49 \pm 0.29 \\
0.063^{\text {ns }}\end{array}$ & $\begin{array}{c}35.36 \pm 0.23 \\
0.093^{\mathrm{ns}}\end{array}$ & $\begin{array}{c}36.59^{b} \pm 0.34 \\
0.012^{*}\end{array}$ \\
\hline \multicolumn{7}{|l|}{ Flock } \\
\hline 1 & 10 & $3.81 \pm 0.08$ & $36.79 \pm 0.41$ & $37.56 \pm 0.29$ & $36.18 \pm 0.32$ & $35.56^{b} \pm 0.42$ \\
\hline 2 & 13 & $3.96 \pm 0.07$ & $37.83 \pm 0.34$ & $38.02 \pm 0.35$ & $35.75 \pm 0.27$ & $38.09^{a} \pm 0.37$ \\
\hline 3 & 10 & $3.87 \pm 0.06$ & $38.12 \pm 0.45$ & $37.96 \pm 0.33$ & $35.36 \pm 0.30$ & $38.16^{a} \pm 0.33$ \\
\hline 4 & 14 & $4.01 \pm 0.08$ & $38.24 \pm 0.27$ & $38.47 \pm 0.36$ & $36.19 \pm 0.36$ & $35.48^{b} \pm 0.43$ \\
\hline 5 & 15 & $3.85 \pm 0.07$ & $37.58 \pm 0.31$ & $37.21 \pm 0.49$ & $35.49 \pm 0.28$ & $36.87^{\mathrm{ab}} \pm 0.36$ \\
\hline$P$ values & & $0.189^{\text {ns }}$ & $0.204^{\mathrm{ns}}$ & $0.423^{\text {ns }}$ & $0.074^{\mathrm{ns}}$ & $0.000 * * *$ \\
\hline
\end{tabular}

$\mathrm{a}, \mathrm{b}$ : Values in the same column with different superscripts are statistically different $(\mathrm{P}<0.05)$. ns: nonsignificant $(\mathrm{P}>0.05)$. $^{*}: \mathrm{P}<0.05, * * *: \mathrm{P}<0.001$.

$\mathrm{kg}$ for Chios x Kivircık (F1) lambs. As is seen from Tables, Chios $\times$ Cine Caparı lambs had lower growth performance $(8.38 \mathrm{~kg}, 16.24 \mathrm{~kg}, 21.09 \mathrm{~kg}$ and 25.86 $\mathrm{kg}$ ) than Chios $\mathrm{x}$ kivircık (F1) lambs. While the differences among the genotypes were statistically significant in terms of only the 90th and 120th day live weights $(P<0.05)$, flocks had a statistically significant effect for all growth period for live weights $(P<0.05)$.

In the current study, some body measurements such as height at withers, rump height, body length, and chest girth values on the 60th day of age were $52.27 \mathrm{~cm}, 51.16 \mathrm{~cm}, 49.29 \mathrm{~cm}$, and $59.78 \mathrm{~cm}$ for the
CK lambs, these values were respectively $51.78 \mathrm{~cm}$, $50.69 \mathrm{~cm}, 48.86 \mathrm{~cm}$, and $59.27 \mathrm{~cm}$ for the CC lambs. The same measurements were detected as $59.67 \mathrm{~cm}$, $59.61 \mathrm{~cm}, 57.18 \mathrm{~cm}$, and $74.71 \mathrm{~cm}$ for the CK lambs, these values were respectively $59.44 \mathrm{~cm}, 59.30 \mathrm{~cm}$, $56.68 \mathrm{~cm}$, and $74.43 \mathrm{~cm}$ for the CC lambs on the 120th day of age. While the differences among the genotypes were statistically significant in terms of only the the 30th day live weights $(P<0.05)$, flocks had a statistically significant effect overall for all growth period for live weights $(P<0.05)$.

Table 4. Least square means for the effects of genotype and flock on growth traits of Chios $x$ KIvircık and Chios $x$ Cine Caparı crossbreed male lambs at age of 30th day $( \pm)$

\begin{tabular}{|c|c|c|c|c|c|c|}
\hline Factor & $\mathrm{n}$ & $\begin{array}{l}\text { 30th day Weight } \\
(\mathrm{kg})\end{array}$ & $\begin{array}{l}\text { Height at Withers } \\
(\mathrm{cm})\end{array}$ & $\begin{array}{l}\text { Rump Height } \\
(\mathrm{cm})\end{array}$ & $\begin{array}{c}\text { Body Length ( } \\
\mathrm{cm})\end{array}$ & $\begin{array}{c}\text { Chest Girth } \\
(\mathrm{cm})\end{array}$ \\
\hline \multicolumn{7}{|l|}{ Genotype } \\
\hline Chios x Kivircık & 34 & $8.70 \pm 0.09$ & $43.95 \pm 0.29$ & $44.07 \pm 0.27$ & $40.86 \pm 0.23$ & $47.78 \pm 0.33$ \\
\hline Chios x Cine Caparı & 22 & $8.38 \pm 0.12$ & $42.76 \pm 0.38$ & $42.70 \pm 0.37$ & $39.94 \pm 0.33$ & $47.26 \pm 0.44$ \\
\hline$P$ values & & $0.209^{\text {ns }}$ & $0.042^{*}$ & $0.036^{*}$ & $0.029 *$ & $0.343^{\mathrm{ns}}$ \\
\hline \multicolumn{7}{|l|}{ Flock } \\
\hline 1 & 9 & $7.94^{b c} \pm 0.16$ & $41.76^{b} \pm 0.55$ & $41.96^{b} \pm 0.54$ & $38.78^{c} \pm 0.42$ & $47.86^{\mathrm{ab}} \pm 0.51$ \\
\hline 2 & 12 & $9.09^{a} \pm 0.15$ & $42.96^{\mathrm{ab}} \pm 0.52$ & $43.37^{\mathrm{ab}} \pm 0.48$ & $39.97^{\mathrm{ab}} \pm 0.41$ & $48.21^{\mathrm{a}} \pm 0.49$ \\
\hline 3 & 9 & $8.82^{\mathrm{ab}} \pm 0.14$ & $44.33^{\mathrm{a}} \pm 0.50$ & $43.96^{\mathrm{ab}} \pm 0.47$ & $39.36^{\mathrm{b}} \pm 0.40$ & $48.76^{\mathrm{a}} \pm 0.57$ \\
\hline 4 & 12 & $8.12^{c} \pm 0.017$ & $44.87^{\mathrm{a}} \pm 0.54$ & $44.29^{a} \pm 0.44$ & $41.22^{\mathrm{a}} \pm 0.47$ & $45.78^{\mathrm{b}} \pm 0.52$ \\
\hline 5 & 14 & $8.39^{b c} \pm 0.016$ & $43.89^{\mathrm{ab}} \pm 0.52$ & $42.96^{\mathrm{ab}} \pm 0.50$ & $39.04^{c} \pm 0.43$ & $47.31^{\mathrm{ab}} \pm 0.50$ \\
\hline$P$ values & & $0.001 * * *$ & $0.001 * *$ & $0.034 *$ & $0.041^{*}$ & $0.022 *$ \\
\hline
\end{tabular}

a,b,c: Values in the same column with different superscripts are statistically different $(P<0.05)$. ns: nonsignifican $(P>$ $0.05)$. ${ }^{*} \mathrm{P}<0.05, * *: \mathrm{P}<0.01, * * *: \mathrm{P}<0.001$. 
Table 5. Least square means for the effects of genotype and flock on growth traits of Chios x Kivircık and Chios $x$ Cine Caparı crossbreed male lambs at age of 60th day $( \pm)$

\begin{tabular}{|c|c|c|c|c|c|c|}
\hline Factor & $\mathrm{n}$ & $\begin{array}{l}\text { Birth Weight } \\
(\mathrm{kg})\end{array}$ & $\begin{array}{l}\text { Height at Withers } \\
(\mathrm{cm})\end{array}$ & $\begin{array}{l}\text { Rump Height } \\
(\mathrm{cm})\end{array}$ & $\begin{array}{l}\text { Body Length } \\
\quad(\mathrm{cm})\end{array}$ & $\begin{array}{c}\text { Chest } \\
\text { Girth }(\mathrm{cm})\end{array}$ \\
\hline \multicolumn{7}{|l|}{ Genotype } \\
\hline Chios x Kıvırcık & 31 & $16.75 \pm 0.18$ & $52.27 \pm 0.22$ & $51.16 \pm 0.24$ & $49.29 \pm 0.21$ & $59.78 \pm 0.33$ \\
\hline Chios $x$ Cine Caparı & 21 & $16.24 \pm 0.22$ & $51.78 \pm 0.29$ & $50.69 \pm 0.39$ & $48.86 \pm 0.28$ & $59.27 \pm 0.39$ \\
\hline$P$ values & & $0.207^{\mathrm{ns}}$ & $0.387^{\mathrm{ns}}$ & $0.293^{\mathrm{ns}}$ & $0.181^{\mathrm{ns}}$ & $0.235^{\mathrm{ns}}$ \\
\hline \multicolumn{7}{|l|}{ Flock } \\
\hline 1 & 8 & $16.28^{b} \pm 0.27$ & $51.86 \pm 0.42$ & $50.31 \pm 0.47$ & $47.85^{b} \pm 0.31$ & $62.57^{\mathrm{a}} \pm 0.47$ \\
\hline 2 & 12 & $17.06^{\mathrm{a}} \pm 0.23$ & $51.52 \pm 0.44$ & $50.88 \pm 0.28$ & $48.58^{\mathrm{ab}} \pm 0.57$ & $61.11^{b} \pm 0.50$ \\
\hline 3 & 8 & $16.38^{\mathrm{b}} \pm 0.18$ & $52.86 \pm 0.45$ & $51.46 \pm 0.36$ & $48.81^{\mathrm{ab}} \pm 0.45$ & $59.38^{c} \pm 0.48$ \\
\hline 4 & 11 & $16.03^{b} \pm 0.32$ & $52.88 \pm 0.43$ & $50.72 \pm 0.44$ & $49.17^{\mathrm{a}} \pm 0.43$ & $57.72^{c} \pm 0.43$ \\
\hline 5 & 13 & $17.04^{a} \pm 0.26$ & $51.62 \pm 0.33$ & $51.30 \pm 0.37$ & $47.77^{b} \pm 0.30$ & $59.44^{c} \pm 0.56$ \\
\hline P values & & $0.035 *$ & $0.289^{\mathrm{ns}}$ & $0.486^{\mathrm{ns}}$ & $0.032 *$ & $0.000 * * *$ \\
\hline
\end{tabular}

$\mathrm{a}, \mathrm{b}, \mathrm{c}$ : Values in the same column with different superscripts are statistically different $(\mathrm{P}<0.05)$. ns: nonsignificant $(\mathrm{P}>$ $0.05)$. * $\mathrm{P}<0.05, * * * \mathrm{P}<0.001$.

\section{Discussion}

In the study, the birth rate and conception rate obtained from Chios $x$ Kivircık hybrid sheep were quite higher than the values (69.05\% and 69.84\%) reported by Yilmaz and Altunel (2003) for Chios x Kivircik crossbred sheep (F1) and the values which close to the litter size (1.3) and single birth rate (71.26\%) reported in the same study were found in this study.

Ceyhan et al. (2007) stated that the lamb yield based on the birth rates and number of ewes mated for Chios sheep was $74.5 \%$ and $1.36 \%$, respectively and in the study conducted by Tekerli et al. (2002) for three years, they stated that the birth rates were $86.6 \%, 77.78 \%$ and $61.54 \%$, respectively and litter sizes were 1.46, 2.14 and 2.50. When the values found in this study were compared with the mentioned studies, it was observed that the birth rate values found in this study were higher and the lambing rate was lower. The high birth and conception rates were considered to be due to controlled mating applications and the intense keep up with mechanisms in the following period.

When the literature data were investigated, it was observed that number of the studies on the fertility rate criteria of Chios $x$ Cine Caparı crossbred sheep was limited. When data reported in Cine Caparı breed registry were compared with the data obtained in this study, it was observed that the birth rate and the litter size were similar values (GDARP, 2009).

While, 30th day survival rate obtained from CK lambs was higher than survival value (89.51) at the same period found in the study by Altnel et al. (1998), in which they used CK lambs, the 30th day survival value of Chios $x$ Çine Çapari lambs value obtained in this study were lower the mentioned study. It was found that the 90th day survival rates of the lambs obtained in this study were quite higher than the 90th day survival value (71.43) reported by Tekerli et al. (2002) for Chios lambs.

The birth weights obtained in this study presented quite higher values to the birth weight $(3.64 \mathrm{~kg})$ stated by Çörekçi and Evrim (2000) for Chios lambs and the live weight values they stated for the 60th and 120th days $(18.70 \mathrm{~kg}$ and $29.61 \mathrm{~kg}$ ) were found to be quite higher than the values found in the current study. In this study, the birth weights obtained from Chios $x$ Kıvırcık and Chios $x$ Cine Çapari lambs were found to be relatively higher than the birth weight value of 3.59 kg stated by Altnel et al. (1998) for Chios x Kivircık (F1) lambs. However, While it was observed that the 30th live weights of the lambs of both genotypes were lower than the values for 30th day $(9.49 \mathrm{~kg}), 60$ th day live weights were similar with 60th day $(16.06 \mathrm{~kg})$ found in the same study. This was considered to be associated with care and feeding inadequacy.

The body length value at birth determined in this study was found to be similar to the body length at birth $(45.4 \mathrm{~cm}, 44.3 \mathrm{~cm}$ and $47.2 \mathrm{~cm})$ stated by Basem and Tabbaa (2011) for Chios x Chios, Chios x Awassi and Awassi $x$ Chios breed lambs.

The 90th day body sizes for the lambs in both genotypes found in this study were compatible with the 90th day height at withers, body length and chest girth values $(55.51 \mathrm{~cm}, 54.42 \mathrm{~cm}$ and $68.27 \mathrm{~cm}$,) stated by Ünal (2002), respectively, for Chios $x$ Akkaraman (F1) lambs. 
Table 6. Least square means for the effects of genotype and flock on growth traits of Chios $x$ Kivircık and Chios $x$ Cine Caparı crossbreed male lambs at age of 90th day ( \pm )

\begin{tabular}{|c|c|c|c|c|c|c|}
\hline Factor & $\mathrm{n}$ & $\begin{array}{l}\text { Birth Weight } \\
(\mathrm{kg})\end{array}$ & $\begin{array}{l}\text { Height at Withers } \\
\qquad(\mathrm{cm})\end{array}$ & $\begin{array}{l}\text { Rump Height } \\
\text { (cm) }\end{array}$ & $\begin{array}{l}\text { Body Length } \\
(\mathrm{cm})\end{array}$ & $\begin{array}{c}\text { Chest } \\
\text { Girth }(\mathrm{cm})\end{array}$ \\
\hline \multicolumn{7}{|l|}{ Genotype } \\
\hline Chios x Kivircık & 30 & $22.02 \pm 0.22$ & $55.89 \pm 0.21$ & $55.11 \pm 0.23$ & $54.07 \pm 0.20$ & $69.03 \pm 0.39$ \\
\hline Chios $x$ Cine Caparı & 21 & $21.09 \pm 0.36$ & $55.51 \pm 0.32$ & $54.83 \pm 0.32$ & $53.96 \pm 0.33$ & $68.60 \pm 0.44$ \\
\hline$P$ values & & $0.017^{*}$ & $0.446^{\mathrm{ns}}$ & $0.128^{\mathrm{ns}}$ & $0.196^{\mathrm{ns}}$ & $0.203^{\mathrm{ns}}$ \\
\hline \multicolumn{7}{|l|}{ Flock } \\
\hline 1 & 8 & $21.26 \pm 0.37$ & $56.01^{\mathrm{ab}} \pm 0.37$ & $55.50 \pm 0.48$ & $53.19^{b} \pm 0.32$ & $71.01^{\mathrm{a}} \pm 0.38$ \\
\hline 2 & 12 & $22.39 \pm 0.41$ & $54.55^{\mathrm{b}} \pm 0.42$ & $54.21 \pm 0.42$ & $53.42^{b} \pm 0.36$ & $71.53^{\mathrm{a}} \pm 0.51$ \\
\hline 3 & 8 & $20.61 \pm 0.37$ & $56.67^{\mathrm{a}} \pm 0.40$ & $55.40 \pm 0.43$ & $54.24^{\mathrm{ab}} \pm 0.34$ & $68.54^{\mathrm{a}} \pm 0.40$ \\
\hline 4 & 11 & $20.78 \pm 0.40$ & $55.59^{\mathrm{ab}} \pm 0.39$ & $54.87 \pm 0.40$ & $54.02^{\mathrm{a}} \pm 0.37$ & $66.73^{b} \pm 0.46$ \\
\hline 5 & 12 & $21.39 \pm 0.38$ & $55.53^{\mathrm{ab}} \pm 0.35$ & $54.98 \pm 0.42$ & $52.45^{c} \pm 0.28$ & $68.73^{\mathrm{a}} \pm 0.43$ \\
\hline$P$ values & & $0.076^{\mathrm{ns}}$ & $0.024 *$ & $0.088^{\mathrm{ns}}$ & $0.002^{* *}$ & $0.000 * * *$ \\
\hline
\end{tabular}

$a, b, c:$ Values in the same column with different superscripts are statistically different $(P<0.05)$. ns: nonsignificant $(P>$ $0.05){ }^{*}: \mathrm{P}<0.05, * * *: \mathrm{P}<0.001$.

Table 7. Least square means for the effects of genotype and flock on growth traits of Chios $x$ Kivircık and Chios $x$ Cine Caparı crossbreed male lambs at age of 120th day ( \pm )

\begin{tabular}{|c|c|c|c|c|c|c|}
\hline Factor & $\mathrm{n}$ & $\begin{array}{l}\text { Birth Weight } \\
(\mathrm{kg})\end{array}$ & $\begin{array}{l}\text { Height at Wit- } \\
\text { hers }(\mathrm{cm})\end{array}$ & $\begin{array}{l}\text { Rump Height } \\
(\mathrm{cm})\end{array}$ & $\begin{array}{l}\text { Body Length } \\
(\mathrm{cm})\end{array}$ & $\begin{array}{c}\text { Chest } \\
\text { Girth }(\mathrm{cm})\end{array}$ \\
\hline \multicolumn{7}{|l|}{ Genotype } \\
\hline Chios x Kivircık & 30 & $26.89 \pm 0.22$ & $59.67 \pm 0.22$ & $59.61 \pm 0.27$ & $57.18 \pm 0.17$ & $74.71 \pm 0.57$ \\
\hline Chios $x$ Cine Caparı & 21 & $25.86 \pm 0.30$ & $59.44 \pm 0.30$ & $59.30 \pm 0.34$ & $56.68 \pm 0.22$ & $74.43 \pm 0.60$ \\
\hline$P$ values & & $0.033^{*}$ & $0.509^{\text {ns }}$ & $0.543^{\mathrm{ns}}$ & $0.472^{\mathrm{ns}}$ & $0.901^{\text {ns }}$ \\
\hline \multicolumn{7}{|l|}{ Flock } \\
\hline 1 & 8 & $26.75^{\mathrm{ab}} \pm 0.42$ & $58.93^{b} \pm 0.43$ & $60.72^{\mathrm{a}} \pm 0.41$ & $56.70 \pm 0.34$ & $75.10^{\mathrm{ab}} \pm 0.49$ \\
\hline 2 & 12 & $27.51^{\mathrm{a}} \pm 0.40$ & $58.06^{b} \pm 0.38$ & $57.80^{b} \pm 0.40$ & $56.31 \pm 0.33$ & $75.68^{\mathrm{a}} \pm 0.58$ \\
\hline 3 & 8 & $26.22^{\mathrm{ab}} \pm 0.32$ & $60.95^{\mathrm{a}} \pm 0.39$ & $60.27^{\mathrm{a}} \pm 0.38$ & $57.90 \pm 0.28$ & $73.86^{\mathrm{b}} \pm 0.47$ \\
\hline 4 & 11 & $25.23^{b} \pm 0.47$ & $60.08^{\mathrm{ab}} \pm 0.44$ & $59.56^{\mathrm{ab}} \pm 0.46$ & $56.95 \pm 0.29$ & $73.71^{c} \pm 0.50$ \\
\hline 5 & 12 & $25.48^{b} \pm 0.44$ & $59.90^{\mathrm{ab}} \pm 0.42$ & $58.97^{\mathrm{ab}} \pm 0.42$ & $57.17 \pm 0.26$ & $74.91^{\mathrm{ab}} \pm 0.52$ \\
\hline$P$ values & & $0.019 *$ & $0.000 * * *$ & $0.001^{* *}$ & $0.118^{\text {ns }}$ & $0.021 *$ \\
\hline
\end{tabular}

$\mathrm{a}, \mathrm{b}, \mathrm{c}$ : Values in the same column with different superscripts are statistically different $(\mathrm{P}<0.05)$. ns: nonsignificant $(\mathrm{P}>$ $0.05){ }^{*}: \mathrm{P}<0.05, * * *: \mathrm{P}<0.001$.

The study was conducted as semi-extensive under the breeder conditions and it was observed that the floçks had a statistically significant effect on the live weight and body measurements in all the growth periods, except for the birth weights $(P<0.05)$. Similar to the current study, Kul and Akcan (2002) stated that the effect of herd on the growth characteristics of lambs was statistically significant in terms of the body length but this effect was not effective in the 3-month period (except for rump height).

\section{Conclusions}

For the breeders who do not have good economic conditions, it is more important to protect and improve the native breeds with high adaptation skills to their regions rather than bringing culture breed animals from other regions and provide their adaptation. It has been observed that several studies have been conducted usually on fertility traits and growth characteristics in sheep but it may be asserted that the number of studies conducted especially under the breeder conditions is limited. 
Many of the fertility trait findings obtained from Chios $x$ Kivircık and Chios $x$ Cine Capari sheep that are raised locally have similarities among the genotypes but especially the superiority in favor of Chios $x$ Kivircık crossbred in lamb yield, litter size and twinning rate is remarkable. In addition, it was determined that the findings obtained from both genotypes were quite low compared to Chios breed in terms of the lamb yield and they were similar with the lamb yield values of Kıvırcık and Cine Caparı breeds. In the light of these findings, it is considered that the income of local people who live on lambs may be increased by implementing planned reverse Crossbreeding applications and the regular recording studies.

\section{References}

Akçapınar, H. (2000). Koyun yetiştiriciliği. 2nd ed. Ankara, Turkey: İsmat Publishing.

Altınel, A., Evrim, M., Özcan, M., Başpınar, H., \& Deligözoğlu, F. (1998). Studies on possibility of producing high quality lambs by crossbreeding among Sakız, Kıvırcık and German Black Headed mutton sheep. Turkish Journal of Veterinary and Animal Sciences, 22, 257-265

Basem, M. A., \& Tabbaa, M. (2011). Comparison of body weight and dimensions at birth and weaning among Awassi and Chios breeds and their crosses. Jordan Journal of Agricultural Sciences, 7(4), 656666.

Ceyhan, A., Erdoğan, İ., \& Sezenler, T (2007). Some production characteristics of Kivircık, Gokceada and Sakız breeds of sheep conserved as gene resources. Journal of Tekirdag Agricultural Faculty, 4(2), 211217.

Çörekçi, Ş. G., \& Evrim, M. (2000). Comparative studies on the production performances of Chios and Imroz sheep kept under semi-intensive condition III. The effect of some environmental factors on production characteristics. Turkish Journal of Veterinary and Animal Sciences, 24, 553-561 (in Turkish with an abstract in English).

Elmaz, Ö., Saatcı, M., Dağ, B., Aktaş, H. A., Ata, A., Gülay, Ş.M., \& Mamak, N. (2011). Honamlı keçi ırkının çeşitli özelliklerinin tespiti. Project of TUBITAK, No: 109R020.

Ergün, A., Çolpan, İ., Yıldız, G., Küçükersan, S., Tuncer, Ş. D., Yalçın, S., Küçükersan, M. K., \& Şehu, A. (2006). Animal nutrition and nutritional diseases. 3rd ed. Ankara, Turkey: Pozitif Publishing.

Ertuğrul, M., Savaş, T., Dellal, G., Taşkın, T., Koyuncu, M., Cengiz, F., Dağ, B., Koncagül, S., \& Pehlivan E. (2010, January 11-15). Türkiye küçükbaş hayvancılığının iyileştirilmesi. Paper presented at
Türkiye Ziraat Mühendisliği VII. Teknik Kongresi, Ankara, Turkey.

General Directorate of Agricultural Research and Policies (GDARP). (2009). Domestic animal genetic resources in Turkey. Ankara, Turkey.

Görür, O. T., Taşkın, Y., Çıplak, E., Göktaş, G., Polat, N., Akın, K., Özcan, T., Yüksel, S., Arttk, M., \& Sarıca, Y. (2012, June 8-9). Küçükbaş hayvancılığı genel bakış. Küçükbaş Hayvancılık Çalıştay Raporu, Hakkari, Turkey.

Günaydın, G. (2009). Economic and political analysis of Turkish sheep breeding sector. Uludağ Üniversitesi Ziraat Fakültesi Dergisi, 23(2), 15-32.

Hatziminaoglou, I., Georgoudis, A., Zervas, N., \& Boyazoglu. J. (1996). Prolific breeds of Greece. In M. H. Fahmy (Ed). Prolific sheep pp. 73-92. UK: CAB International Press.

Karaca, O., Altn, T., \& Okut, H. (1996). Some parameters estimation on the live weights changes of Karakaş ewes in the rural farms. Yüzüncü Yıl Üniversitesi Ziraat Fakültesi Dergisi, 6(3), 59-72.

Kul, S., \& Akcan, A. (2002). Survival ability, growth and some body measurements in Awassi and East Friesian x Awassi crossbred (F1) lambs. Uludağ Üniversitesi Veteriner Fakültesi Dergisi, 21, 109-114.

Minitab (2010). Minitab 16.1.1 for Windows. State College, PA, USA: Minitab Inc.

Öztürk, D., \& Karkacıer, O. (2008). Süt sığırcılığı yapan işletmelerin ekonomik analizi: Tokat ili Yeşilyurt ilçesi örneği. Gaziosmanpaşa Üniversitesi Ziraat Fakültesi Dergisi, 25(1), 15-22.

Tekerli, M., Gündoğan, M., Akıncı, Z., \& Akcan, A. (2002). Determination of production characteristics of Akkaraman, Daglic, Chios and Awassi sheep in the conditions of Afyon Province. I - Fertility and survival rate. Lalahan Hayvancilık Araştırma Enstitüsü Dergisi, 42(2), 29-36

Turkish Statistical Institute (2020). Hayvansal Üretim istatistikleri. http://www.tuik.gov.tr/PreTablo.do? alt_id=1002/ [Accessed 19 July 2020].

Ünal, N. (2002). Akkaraman ve Sakız x Akkaraman F1 kuzularda yaşama gücü, büyüme ve bazı vücut ölçüleri. Turkish Journal of Veterinary and Animal Sciences, 26, 109-116.

Yılmaz, A., Altnel, A. (2003). The fertility and milk production traits of chios X kivırcık (F1) ewes mated with german black-headed mutton rams to produce crossbred slaughter lambs, in comparison with kıvırcık and turkish merino ewes. istanbul Üniversitesi Veteriner Fakültesi Dergisi, 29(2), 221227. 